\title{
BLESSED IMELDA FEASTDAY: MAY 13
}

Leaving the zeal with the flowers

I slipped off to receive, in the rapture

with which I sank unconscious to see

what appeared-

All the religious life of the rapture with flowers.

Some of them were startled

that I was to be trained there by the tabernacle.

When I, adorned with flowers, was present in the consuming desire

of the priest who hurried forward with a miracle; he could not do otherwise.

My special devotion was so great that it broke.

The nuns were startled to receive it.

I slipped off to be trained there at the earliest age for a miracle; would He not die?

My special devotion was also my last.

There was the priest who hurried forward with flowers.

I was trained there by the priest who hurried forward with flowers with which I was adorned.

All the religious life of the rapture, with flowers, adorned. 